\title{
Nadejście Wieku Półcienia
}

Naomi Oreskes, Erik M. Conway 
Nadejście Wieku Półcienia'

Naomi Oreskes, Erik M. Conway

TEKSTY DRUGIE 2017, NR 3, S. 146-154

DOI: $10.18318 /$ td.2017.3.8
Jest to wstęp oraz pierwszy rozdział książki Naomi Oreskes i Erika M. Conwaya, The Collapse of Western Civilization. A View from the Future (Columbia University Press, New York 2014). Książka ukaże się w październiku 2017 roku nakładem Wydawnictwa Naukowego PWN (Upadek cywilizacjizachodniej. Spojrzenie z przyszłości, przeł. Ewa Bińczyk, Jakub Gużyński, Krzysztof Tarkowski). Druk fragmentu za zgodą wydawcy.

\section{Wstęp}

Pisarze science fiction tworzą wyobrażoną przyszłość, historycy próbują rekonstruować przeszłość. Ostatecznie zarówno jedni, jak i drudzy dążą do zrozumienia teraźniejszości. W niniejszym eseju łączymy oba gatunki narracji, próbując wyobrazić sobie historyka z przyszłości, który ocenia przeszłość będącą naszą obecną i (możliwą) przyszłością. Okazją ku temu jest trzechsetlecie końca kultury Zachodu (datowanej na lata 1540-2093). Dylemat, z którym zmaga się nasz historyk z przyszłości, dotyczy tego, jakim cudem my - potomkowie oświecenia - nie zdołaliśmy w swoich działaniach uwzględnić ani solidnych informacji na temat zmiany klimatycznej, ani wiedzy na temat katastrofalnych zdarzeń, które wkrótce miały się rozegrać. Nasz historyk dochodzi do wniosku, że Cywilizacja Zachodnia kolejny raz weszła w wieki ciemne, w których wyparcie (denial) i samooszukiwanie

\section{Naomi Oreskes -}

historyk nauki (Uniwersytet Harvarda).

\section{Erik M. Conway}

historyk nauki i technologii (Kalifornijski Instytut Technologiczny). Autorzy książki Merchants of Doubt (2010), opisującej kampanie dezinformacyjne dotyczące m.in. szkodliwości palenia, i eseju Science-fiction The Collapse of Western Civilization.

1 Opracowanie przekładu zostało przygotowane $\mathrm{w}$ ramach realizacji projektu badawczego 2016/21/B/HS1/00829 realizowanego przez Narodowe Centrum Nauki. 
zakorzenione w ideologicznym zafiksowaniu na „wolnym" rynku obezwładniło najpotężniejsze narody świata w obliczu tragedii. Co więcej, naukowcy, którzy najlepiej rozumieli problem, zostali sparaliżowani przez swe własne praktyki kulturowe, zgodnie z którymi akceptacja jakichkolwiek twierdzeń, nawet tych dotyczących bezpośrednich zagrożeń, wymaga stosowania wyjątkowo ścisłych standardów. Nasz historyk z przyszłości żyjący w Drugiej Chińskiej Republice Ludowej przywołuje tu wydarzenia Okresu Półcienia (1988-2093), które doprowadziły do Wielkiego Upadku i Masowej Migracji (2073-2093).

Państwo znane onegdaj jako Niderlandy, określane kiedyś „Krajami Nizinnymi" Europy. Między XVI a XX stuleciem dzięki intensywnym wysiłkom ludzkim udało się wyrwać morzu większość terenów zajmowanych przez te kraje. Zaskakująco szybkie podniesienie się poziomu morza w okresie

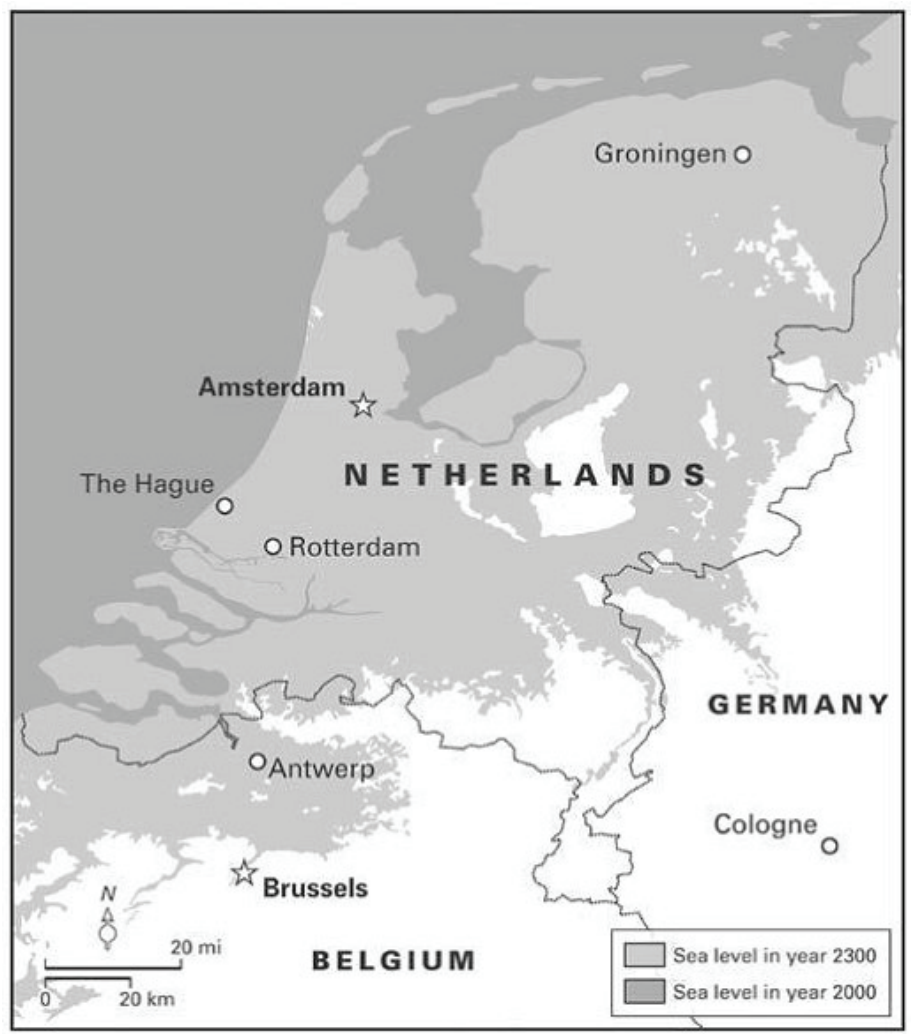


Wielkiego Upadku zaskoczyło holenderskich obywateli i obywatelki. Potomkowie i potomkinie ocalałych zasiedlają w większości tereny Unii Nordycko-Skandynawskiej, zaś rdzewiejące drapacze ich zatopionych miast są upiornym świadectwem wspaniałej przeszłości.

\section{Nadejście Wieku Półcienia}

Pradzieje „cywilizacji” znały wiele społeczeństw, które rozkwitały i upadały, jednak tylko nieliczne z nich pozostawiły po sobie tak przejrzyste i szczegółowe wyjaśnienia dotyczące tego, co i dlaczego im się przydarzyło, jak państwa narodowe XXI wieku, określające się mianem Cywilizacji Zachodniej. Nawet współcześnie, dwa tysiące lat po rozpadzie imperium rzymskiego i cywilizacji Majów oraz tysiąc lat po upadku Bizancjum i cywilizacji Inków, historycy, archeologowie i paleoanalitycy niepowodzenn ${ }^{2}$ nie potrafią dojść do porozumienia na temat podstawowych przyczyn utraty przez wspomniane społeczeństwa zdolności reprodukcyjnych, władzy, stabilności i tożsamości. Przypadek Cywilizacji Zachodniej jest inny, ponieważ skutki jej funkcjonowania nie tylko pozwalały się przewidzieć, lecz faktycznie zostały przewidziane. Co więcej, to społeczeństwo okresu przejściowego pozostawiło po sobie mnóstwo danych, zarówno pod postacią typowych dla XX-wiecznego stylu zapisów papierowych, jak i elektronicznych formatów XXI stulecia. Pozwala nam to zrekonstruować niezwykle bogate szczegóły przeszłych wydarzeń. Choć analitycy mają różne opinie na temat dokładnych okoliczności omawianych wypadków, praktycznie wszyscy zgadzają się co do tego, że ludzie Cywilizacji Zachodniej wiedzieli, co się im przydarza. Nie byli jednak w stanie tego powstrzymać. W rzeczy samej, najbardziej zadziwiające w omawianej historii jest właśnie to, jak wiele wiedzieli ci ludzie i do jakiego stopnia nie potrafili wykorzystać tej wiedzy w działaniu. Wiedza nie zamieniła się tu we władzę.

Przez ponad sto lat poprzedzających upadek świat Zachodu zdawał sobie sprawę z tego, że znajdujące się w atmosferze ziemskiej dwutlenek węgla (CO2) i para wodna pochłaniają ciepło. Trzy następujące po sobie etapy rewolucji przemysłowej doprowadziły do masowego uwolnienia dodatkowych ilości $\mathrm{CO}_{2}$ do atmosfery, początkowo w Zjednoczonym Królestwie (1750-1850), następnie w Niemczech, Stanach Zjednoczonych, w innych krajach europejskich i w Japonii (1850-1980), a na koniec w Chinach, Indiach

2 Na temat paleoanalizy niepowodzeń (synthetic-failure paleoanalysis) zob. Leksykon dawnych pojęć w niniejszym tomie [przyp. tłum]. 
i Brazylii (1980-2050). (W eseju używam terminów odnoszących się do państw narodowych omawianej epoki. Dla czytelnika nieobeznanego z geografią polityczną Ziemi sprzed Wielkiego Upadku dodajmy, że Zjednoczone Królestwo leżało na terenach dzisiejszej Kambrii [Cambria], Niemcy w Unii Nordycko-Skandynawskiej, zaś Stany Zjednoczone i Kanada na terenie Stanów Zjednoczonych Ameryki Północnej.) Na początku ostatecznej fazy upadku, w połowie XX wieku, niektórzy przyrodoznawcy - określani w ten sposób dlatego, że zgodnie z archaiczną konwencją Zachodu badali świat fizyczny w izolacji od systemów społecznych - rozpoznali, że spowodowany działalnością człowieka wzrost poziomu $\mathrm{CO}_{2} \mathrm{w}$ atmosferze teoretycznie może ogrzać planetę. Przejęli się tym tylko nieliczni. Suma emisji była wciąż dość niska. Zresztą, większość naukowców uznawała atmosferę za w zasadzie nieograniczony śmietnik. W latach 6o. XX wieku mówiono często, że „rozcieńczanie to zanieczyszczeń likwidowanie" ["the solution to pollution is dilution"].

Sytuacja zaczęła się zmieniać, gdy ścieki czy śmietniki planetarne zaczęły się zbliżać do stanu przepełnienia, a „rozcieńczanie” zanieczyszczeń okazało się niewystarczające. Niektóre zanieczyszczenia chemiczne, takie jak chloroorganiczne środki owadobójcze (szczególnie pestycyd dichlorodifenylotrichloroetan, czyli DDT) i freony (CFC) wywoływały bardzo silne efekty nawet przy bardzo niskich stężeniach. W latach 6o. XX wieku okazało się, że DDT zaburza funkcje rozrodcze ryb, ptaków i ssaków. W latach 70. XX wieku naukowcy poprawnie przewidzieli, że CFC uszkodzi warstwę ozonową w stratosferze. Z powodu ogromnej ilości substancji usuwanych do środowiska wystąpiły kolejne skutki przesycenia. Do substancji tych należały siarczany wytwarzane podczas spalania węgla, a także $\mathrm{CO}_{2}$ i metan $\left(\mathrm{CH}_{4}\right)$, pochodzące z mnóstwa źródeł, włącznie ze spalaniem paliw kopalnych, produkcją betonu, wylesianiem, a także dominującymi w omawianych czasach technikami produkcji ryżu na polach ryżowych i wołowiny (stanowiącej podstawowe źródło białka).

W latach 70. XX wieku naukowcy zaczęli dostrzegać, że działalność człowieka w istotny sposób zmienia fizyczne i biologiczne funkcje planety - co powoduje przejście do nowego okresu w geologicznej historii Ziemi - antropocenu ${ }^{3}$. Naukowcy, którzy dokonali tych wczesnych odkryć, wcale nie byli szczególnie wizjonerscy: wiele istotnych badań było efektem ubocznym testów i prac nad bronią nuklearną ${ }^{4}$. Jedynie z rzadka badacze - w tamtych

Zob. https://quaternary.stratigraphy.org/workinggroups/anthropocene/.

4 R. Doel Constituting the Postwar Earth Sciences. The Military's Influence on the Environmental Sciences in the USA after 1945, "Social Studies of Science" 2003, no. 33, s. 535-666; Naomi Ore- 
czasach dyskryminacja z uwagi na płeć wciąż była powszechna - rozumieli, że tak naprawdę studiują granice śmietników planetarnych. Godnym uwagi wyjątkiem był futurysta Paul Ehrlich, którego książka Bomba populacyjna zdobyła popularność w późnych latach 6o. XX wieku, lecz do lat 9o. XX wieku została już uznana za zdyskredytowaną5.

Niemniej jednak zebrano wystarczającą ilość wyników badań, by sprowokować do jakiejś odpowiedzi. Uruchomiono szeroko zakrojone programy badawcze i powołano nowe instytucje, których celem było potwierdzenie i zbadanie omawianej kwestii. Dzięki ustanowieniu corocznych obchodów Dnia Ziemi (jakby każdy dzień nie był dniem Ziemi!) zachęcano w obszarze kultury do tego, by uczcić planetę. Powołanie Agencji Ochrony Środowiska (Environmental Protection Agency - EPA) w Stanach Zjednoczonych dało podstawy formalne pojęciu ochrony środowiska. Do końca lat 8o. XX stulecia naukowcy wiedzieli już, że koncentracja $\mathrm{CO}_{2}$ i innych gazów cieplarnianych wywiera zauważalny wpływ na klimat planety, skład chemiczny oceanów i systemy biologiczne, grożąc poważnymi konsekwencjami, o ile proces ten nie zostanie niezwłocznie poddany kontroli. Różne grupy i jednostki zaczęły argumentować na rzecz ograniczenia emisji gazów cieplarnianych, namawiając do rozpoczęcia procesu przejścia do alternatywnych źródeł dostarczania energii, nieopartych na węglu.

Zdaniem historyków rok 1988 to początek Wieku Półcienia. Światowi przywódcy polityczni i eksperci naukowi powołali wówczas nową, hybrydową, naukowo-rządową organizację, Międzyrządowy Zespół ds. Zmian Klimatu (Intergovernmental Panel on Climate Change - IPCC). Celem IPCC było komunikowanie istotnych osiągnięć nauki oraz kształtowanie planety i poglądów jej mieszkańców. Rok później Protokół montrealski w sprawie kontroli substancji zubażających warstwę ozonową stał się wzorcem dla zarządzania na poziomie międzynarodowym mającego na celu ochronę atmosfery. Natomiast w roku 1992 na podstawie tego wzorca narody świata podpisały Ramową konwencję Narodów Zjednoczonych w sprawie zmian klimatu (The United Nations Framework Convention on Climate Change - UNFCCC). Jej celem było zapobieżenie „niebezpiecznym antropogenicznym ingerencjom” w system klimatyczny.

skes Science on a Mission. American Oceanography from the Cold War to Climate Change, University of Chicago Press, Chicago ( $w$ druku).

5 P. Ehrlich The Population Bomb, Ballantine Books, New York 1968.Zob. też P.R. Ehrich, A. H. Ehrlich Can a Collapse of Global Civilization be Avoided? "Proceedings of the Royal Society B" 2013, no. 280, http://www.uvm.edu/pdodds/research/papers/files/2013/erlich2013a.pdf. 
Wydawało się, że świat rozpoznał nadciągający kryzys, przedsiębiorąc kroki mające na celu wynegocjowanie i wdrożenie stosownych rozwiązań.

Zanim jednak ruch na rzecz zmiany mógł w ogóle się przyjąć, nastąpiła reakcja (backlash). Krytycy twierdzili, że stopień naukowej niepewności był zbyt wysoki, ażeby uzasadnić wydatki i niedogodności związane z eliminacją emisji gazów cieplarnianych. Podkreślano, że jakakolwiek próba rozwiązania problemu będzie kosztowała więcej niż warte jest to całe przedsięwzięcie. Początkowo jedynie garstka osób (w większości ze Stanów Zjednoczonych) wysuwała takie argumenty. (Z perspektywy czasu tendencja USA do samousprawiedliwiania się wydaje się oczywista, nie było to jednak dla wielu jasne, przynajmniej w tamtym momencie). Niektóre kraje próbowały (choć im się to nie udało) zmusić Stany Zjednoczone do współpracy międzynarodowej. Inne kraje wykorzystały bierność USA jako wymówkę, by kontynuować własny, destrukcyjny rozwój.

Do końca tysiąclecia sceptycyzm wobec zmiany klimatycznej ${ }^{6}$ stał się bardzo popularny. Przywódcy polityczni w USA - włączając w to prezydenta, członków Kongresu i członków innych ciał ustawodawczych - zajęli pozycje sceptyczne. W Europie, Australii i Kanadzie przemysłowcy, bankierzy i niektórzy przywódcy polityczni upowszechniali przekaz podkreślający „niepewność" danych dotyczących zmiany klimatycznej. W międzyczasie w krajach nisko uprzemysłowionych wyłoniła się inna wersja sceptycyzmu, głosząca, że zagrożenie zmiany klimatu jest wykorzystywane do tego, by zapobiec ich rozwojowi. (Twierdzenia tego rodzaju nie przyniosły jednak znaczących skutków środowiskowych, ponieważ kraje nisko uprzemysłowione emitowały niewielkie ilości gazów cieplarnianych i zasadniczo nie odgrywały wielkiej roli na arenie międzynarodowej).

Istniały jednak godne uwagi wyjątki. Na przykład Chiny podjęły kroki mające na celu kontrolę własnej populacji oraz przekształcenie gospodarki w taki sposób, by opierała się na alternatywnych źródłach pozyskiwania energii. Wysiłków tych nie dostrzeżono i nie naśladowano na Zachodzie,

6 Autorzy posługują się określeniem "climate change denialism", który tłumaczymy w pracy jako "sceptycyzm wobec zmiany klimatycznej" (określenie, które przyjęło się w polskiej literaturze przedmiotu), w wybranych zaś miejscach jako "denializm" (gdy chodzi o zaprzeczanie faktowi antropogenicznej zmiany klimatycznej czy też o mechanizmy wyparcia). Denializm (ang. denial - zaprzeczenie) to irracjonalna postawa związana z odrzucaniem faktów naukowych, co do których panuje powszechna naukowa zgoda. Najjaskrawszymi przykładami denializmu jest zaprzeczenie Holocaustowi (kłamstwo oświęcimskie) oraz zaprzeczanie antropogenicznym przyczynom globalnego ocieplenia klimatu [przyp. tłum]. 
częściowo dlatego, że mieszkańcy Zachodu uznawali chińskie próby kontroli populacji za niemoralne, zaś częściowo dlatego, że wyjątkowo szybka ekspansja gospodarcza Chin przyczyniła się do dramatycznego wzrostu poziomu emisji gazów cieplarnianych, neutralizując skutki uruchomienia odnawialnych źródeł energii. Do roku 2050 efekty uruchomienia odnawialnych źródeł energii w Chinach stały się widoczne, bowiem emisje w tym kraju zaczęły gwałtownie spadać. Gdyby inne narody podążyły za przykładem Chin, historia, którą tu opisujemy, potoczyłaby się zupełnie inaczej'

Jednak w rzeczywistości do początlów XXI wieku niebezpieczna ingerencja człowieka w system klimatyczny postępowała. Coraz częściej pojawiały się pożary, powodzie, huragany i fale upałów. Jednak efekty te wciąż były ignorowane. Ci, których możemy nazwać aktywnymi sceptykami, podkreślali, że ekstremalne zjawiska pogodowe świadczą o naturalnej zmienności, choć nie dysponowali dowodami wspierającymi tezy tego rodzaju. Bierni sceptycy nie rezygnowali ze swego dotychczasowego stylu życia, nieprzekonani co do istnienia wiarygodnych dowodów na rzecz konieczności wprowadzenia głębokich zmian w przemyśle i infrastrukturze. Przyrodoznawcy badający stale nasilające się kataklizmy nie pomogli w rozproszeniu sceptycyzmu, wikłając się zamiast tego w wyrafinowane spory na temat „atrybucji” poszczególnych zdarzeń pogodowych. Rzecz jasna, groźba, która zawisła nad cywilizacją, nie sprowadzała się do pojedynczej powodzi, fali upałów czy huraganu. Chodziło o całościową destabilizację systemu klimatycznego oraz jej wpływ na kriosferę, jak również o wzrastające zakwaszenie oceanów. Jednakże dla naukowców, wyszkolonych do ról ekspertów skupionych na badaniu określonego aspektu funkcjonowania atmosfery, hydrosfery, kriosfery czy biosfery wyrażanie i rozpowszechnianie wiedzy na temat rozległego procesu destabilizacji było trudne.

Rok 2009 uznaje się za "ostatnią szansę" świata zachodniego na uratowanie samego siebie. Przywódcy zachodni spotkali się wówczas w Kopenhadze, w Danii po raz piętnasty od podpisania konwencji UNFCCC, by spróbować wypracować konsensus dotyczący wiążącego prawa międzynarodowego, które miałoby na celu zapobieżenie destruktywnej zmianie klimatu. Dwa lata wcześniej naukowcy zaangażowani w działalność IPCC ogłosili, że antropogeniczne ocieplenie klimatu jest „bezdyskusyjne”, zaś sondaże opinii publicznej pokazywały, że większość obywateli - nawet w opornych Stanach Zjednoczonych - była przekonana o potrzebie podjęcia działań. Jednakże na

7 Na temat różnych sposobów kontroli populacji w Chinach zob. S. Greenhalgh Just One Child. Science and Policy in Deng's China, University of California Press, Berkeley 2008. 
krótko przed spotkaniem w Kopenhadze uruchomiono szeroko zakrojoną kampanię mającą na celu zdyskredytowanie naukowców, których badania leżały u podstaw konkluzji IPCC. Kampania ta została sfinansowana przez korporacje sektora paliwowego. W omawianym okresie roczne zyski tych przedsiębiorstw przewyższały PKB większości krajówº . (W dyskutowanym czasie większość państw wciąż wykorzystywała archaiczne pojęcie produktu krajowego brutto, mierzącego poziom konsumpcji, zamiast bhutańskiego wskaźnika szczęścia narodowego brutto, określającego poziom dobrobytu). Publiczne wsparcie dla działań na rzecz klimatu osłabło, nawet prezydent Stanów Zjednoczonych nie zdołał nakłonić do nich swojego narodu.

W międzyczasie zmiany klimatyczne stawały się coraz bardziej intensywne. Latem 2010 roku rekordowo wysokie upały oraz pożary doprowadziły do śmierci ponad 50 ooo osób w Rosji, przynosząc straty w wysokości 15 miliardów dolarów amerykańskich (według wartości z 2009 roku). Kolejnego roku wielkie powodzie w Australii dotknęły ponad 250000 ludzi. Zimą 2012 roku, który określono w USA „rokiem bez zimy”, odnotowano zupełnie rozchwiane wyniki pomiarów temperatur (włączając w to pomiary najniższych temperatur w nocy) - co w oczywisty sposób powinno zaniepokoić. Nastąpiło po tym lato z niespotykanymi falami upałów, które przyczyniły się do strat w hodowli i rolnictwie. Etykietka "roku bez zimy” okazała się myląca, ponieważ ciepła zima dotyczyła jedynie Stanów Zjednoczonych, ale niechlubny rok 2023 - „rok nieustającego lata” już w pełni zasługiwał na swą nazwę, odbierając życie 500 ooo osób na całym świecie i powodując straty rzędu niemal 500 miliardów dolarów, wywołane przez pożary, nieurodzaj, śmiertelność inwentarza i zwierząt domowych.

Utrata psich i kocich ulubieńców przylkuła uwagę zamożnych mieszkańców Zachodu, jednak to, co było anomalią w roku 2023, wkrótce okazało się nową normalnością. Nawet wówczas politycy, biznesmeni i przywódcy religijni odmówili przyjęcia do wiadomości tego, że narastające niszczycielskie skutki omawianych katastrof mają coś wspólnego ze spalaniem paliw kopalnych. Zwiększenie ilości ciepła w atmosferze oznaczało zwiększenie się ilości energii, która musiała ulec rozproszeniu, co manifestowało się w postaci coraz potężniejszych deszczy, większych wylewów i poważniejszych susz. Było to tak proste. Jednak ludzie, którzy uznawali się za dzieci oświecenia, pozostawali w cieniu ignorancji i zaprzeczeń. To właśnie dlatego omawiane czasy nazywamy dziś Wiekiem Półcienia.

8 Zob.http://unfccc.int/meetings/copenhagen_dec_2009/meeting/6295.php. 
Jasne jest, że na początku XXI stulecia należało podjąć natychmiastowe kroki w celu przekierowania gospodarki na tory nieemisyjne. Co zdumiewające, wydarzyło się coś zupełnie przeciwnego. W tym samym momencie, gdy potrzeba natychmiastowego przekształcenia źródeł pozyskiwania energii stała się oczywista, światowe emisje gazów cieplarnianych wzrosły. Tak trudno to zrozumieć, że musimy przyjrzeć się bliżej naszej wiedzy historycznej na temat tego decydującego momentu.

Przekład i opracowanie naukowe Ewa Bińczyk, Jakub Gużyński, Krzysztof Tarkowski

\section{Abstract}

\section{Naomi Oreskes}

HARVARD UNIVERSITY

\section{Erik M. Conway}

CALIFORNIA INSTITUTE OFTECHNOLOGY

The Coming of the Penumbral Age

This article describes the coming of the Penumbral Period, and the fall of Western civilization. Historians view 1988 as the start of the Penumbral Period, when world scientific and political leaders created a new, hybrid scientific-governmental organization, the Intergovernmental Panel on Climate Change (IPCC), to communicate relevant science, and form the foundation for international governance to protect the planet and its inhabitants. But critics claimed that the scientific uncertainties were too great to justify the expense, and the inconvenience of eliminating greenhouse gas emissions, and climate change denial spread widely by the end of the millennium. The year 2009 is viewed as the "last best chance" for the Western world to save itself, as leaders met in Copenhagen, Denmark, to try to agree on a binding, international law to prevent disruptive climate change. However, in 2023, the leaders still refused to accept that what lay behind the increasing destructiveness of disasters was the burning of fossil fuels.

\section{Keywords}

Penumbral Period; Western civilization; Intergovernmental Panel on Climate Change (IPCC); greenhouse gas emissions; climate change denial; fossil fuels; climate change 